\title{
Home-state regulation of corporations
}

\author{
Daniel Augenstein
}

\section{Introduction}

Home-state regulation of corporations refers to legislation, adjudication, and other regulatory measures aimed at preventing and redressing business-related human rights violations in the host state of corporate investment (Zerk 2006, pp. 145-197). In the most common model, the home state imposes on corporate actors and activities within its territorial jurisdiction regulatory (due diligence) requirements that apply throughout the corporate group and the global supply/value chain. The business and human rights debate about home-state regulation centres on two interrelated issues: first, the extent to which international law imposes obligations on states to prevent and redress business-related human rights violations for the benefit of individuals located outside their territory (international extraterritorial obligations); and second, the extent to which states could and should use domestic law to regulate the extraterritorial human rights impacts of business enterprises (domestic regulation with extraterritorial effect).

The UN Guiding Principles on Business and Human Rights (UNGPs), endorsed by the Human Rights Council in 2011, encourage states to regulate business actors and activities with extraterritorial effect. Yet, they did not clearly recognise corresponding state obligations to prevent and redress business-related human rights violations outside their territory:

At present states are not generally required under international human rights law to regulate the extraterritorial activities of business domiciled within their territory and/or jurisdiction. Nor are they generally prohibited from doing so, provided there is a recognised jurisdictional basis. Within these parameters, some human rights treaty bodies recommend that home state take steps to prevent abuse by business enterprises within their jurisdiction.

(HRC 2011, Principle 2)

The chapter traces a gradual convergence between the regulatory models that underpin these different (international \& domestic) domains of legal ordering one decade after the endorsement of the UNGPs. It is argued that the location of business actors and activities within the state's territorial jurisdiction not only justifies domestic regulation with extraterritorial effect but also grounds international obligations to prevent and redress extraterritorial corporate 
human rights abuse. This convergence suggests the emergence of a new legal consensus on business and human rights, according to which states' regulation of the global human rights impacts of business enterprises are anchored in international legal obligations toward foreign victims of business-related human rights violations.

Section 2 discusses doctrinal developments in international law galvanised by the Maastricht Principles on Extraterritorial Obligations of States in the Area of Economic, Social, and Cultural Rights (Maastricht Principles) that link states' extraterritorial human rights obligations to authority, power, or control they may exercise over business actors and activities within their territorial jurisdiction. Section 3 discusses states' increasing use of domestic law to impose legal due diligence requirements on these business actors and activities that reach out into the global supply/ value chain. While most existing examples of home-state regulation fall short of the requirements for extraterritorial human rights protection laid down in the Maastricht Principles, they are evidence of a growing recognition among states that corporate respect for human rights should be brought under the purview of (international) human rights law.

\section{Home-state regulation in international law}

\section{International extraterritorial obligations: $A$ restrictive approach}

The extent to which states are permitted and/or required to regulate the human rights impacts of business enterprises for the benefit of individuals located outside their territory depends on the relationship between territory and jurisdiction in international law. Jurisdiction circumscribes the scale and scope of international human rights obligations by predicating them upon a sufficiently concrete normative relation of authority, power, or control between the state qua duty-bearer and the individual rights-holder (Besson 2012). At the most general level, two countervailing principles inform the relationship between jurisdiction and extraterritorial human rights obligations (den Heijer and Lawson 2013; Augenstein and Kinley 2013). On the one hand, a state's exercise of jurisdiction to protect human rights outside its borders should not unduly interfere with the sovereign rights that third states wield over their territory and people therein. This explains why the scope of extraterritorial human rights obligations is commonly delimited by states' jurisdictional competence, determined on the basis of a recognised basis of jurisdiction in public international law (the territoriality principle; the nationality principle; etc.). On the other hand, a state should not be permitted to circumvent its international human rights obligations by exceeding its jurisdictional competences in public international law. This explains why the decisive criterion for allocating human rights obligations to states is not the international lawfulness of the extraterritorial exercise of state powers but a jurisdictional relationship of authority, power, or control between the state and an individual located outside its borders (European Court of Human Rights (ECtHR) 2011; Inter-American Commission on Human Rights (IACHR) 1999). ${ }^{1}$

While the text of international human rights treaties does not suggest that states' human rights obligations should be confined to individuals within their borders, concerns with state sovereignty have nevertheless tended international courts towards a 'primarily territorial' interpretation of human rights jurisdiction (International Court of Justice (ICJ) 2004, para 109). In Al Skeini - one of the leading cases on the extraterritorial application of the European Convention - the European Court of Human Rights considered that 'jurisdiction is presumed to be exercised normally throughout the state's territory. Conversely, acts of the contracting states performed, or producing effects, outside their territories can constitute an exercise of jurisdiction within the meaning of Article 1 ECHR only in exceptional circumstances (ECtHR 2011, 
para 131). Similarly, the Inter-American Court of Human Rights noted in a more recent Advisory Opinion on the Environment and Human Rights that whereas jurisdiction was not confined to territory, the conditions under which extraterritorial state conduct qualifies as an exercise of jurisdiction within the meaning of Article 1 IACHR required a restrictive interpretation (IACtHR 2017, para 81).

The two constellations of extraterritorial jurisdiction recognised by the ECtHR in Al Skeiniacts 'performed' and 'producing effects' outside the state's territory - correspond to a more commonly used distinction between extraterritorial state conduct and the extraterritorial effects of states' domestic laws and policies. As traditionally framed in the case-law, neither constellation easily lends itself to establishing home-state obligations to prevent and redress business-related human rights violations for the benefit of individuals located outside its borders. Establishing extraterritorial jurisdiction through acts 'performed' outside the state's territory requires state agents to exercise authority, power, or control over persons and/or an area located on the territory of another state (ECtHR 2011, paras 134-138). Accordingly, traditional variations of the 'control over persons' test (such as the detention or abduction of individuals) and the 'control over an area' test (such as military occupation) are premised on the physical presence of homestate agents on foreign soil. In the standard case of home-state regulation, by contrast, the extraterritorial human rights violation is committed by a non-state actor operating in the host state of corporate investment.

The best-known examples of 'extraterritorial effects' cases concern the extradition or deportation of an individual to a country where she faces substantial risks of serious human rights violations (non-refoulement). The protection of non-refoulement extends to threats to human rights caused by private (non-state) actors abroad (ECtHR 2016). In Rantsev, the ECtHR furthermore recognised that states can be under an obligation to regulate private actors on their own territory in order to prevent and redress human rights violations committed outside their borders (ECtHR 2010). Nevertheless, both in non-refoulement cases and in the Rantsev scenario, the necessary jurisdictional link is established through the victim's initial presence on (home) state's territory. In the standard case of home-state regulation, by contrast, a constituent part of the parent - or controlling - company will be domiciled within the state's territorial jurisdiction while the victim is permanently located on the territory of the host state of corporate investment.

There is some case-law to suggest that the European Court of Human Rights is prepared to recognise extraterritorial human rights obligations absent effective control over a foreign person/area (ECtHR 2015) and to dispense with the requirement that the applicant in extraterritorial effects cases must be located on the state's territory (ECtHR 2012). Moreover, foreign victims seeking to vindicate their human rights through private litigation in the domestic courts of the home state can come under that state's international human rights jurisdiction (ECtHR 2006). However, this case-law has not yet translated into a robust and coherent approach to international extraterritorial obligations to prevent and redress business-related human rights violations.

\section{With power comes responsibility}

A guiding assumption behind the restrictive approach to international extraterritorial obligations is that perpetrators and victims of business-related human rights violations will reside in the same territorial space and will therefore be subject to the authority, power, or control of a single state. This state-sovereigntist approach not only belittles the 'governance gaps' created by, and the transnational human rights impacts of, global supply and value chains (HRC 2008), but it also fails to respond to a core concern in the business and human rights domain, namely 
human rights obligations of the home state of the parent - or controlling - company of 'multinational' corporations to prevent and redress human rights violations committed in the host state of corporate investment (Augenstein 2018).

The Maastricht Principles - a set of non-legally binding principles adopted by a group of human rights experts in 2011 - address this concern by supplementing international extraterritorial obligations with 'obligations relating to the acts and omissions of a state, within or beyond its territory, that have effects on the enjoyment of human rights outside that state's territory' (Principle 8a). This considerably broadens the scope of extraterritorial state obligations to prevent business-related human rights violations:

All states must take necessary measures to ensure that non-state actors which they are in a position to regulate, as set out in Principle 25, such as private individuals and organisations, and transnational corporations and other business enterprises, do not nullify or impair the enjoyment of economic, social and cultural rights. These include administrative, legislative, investigative, adjudicatory and other measures.

(Principle 24)

Pursuant to Principle 25, circumstances under which a home state is in a position to regulate corporate actors and activities abroad include 'where the corporation, or its parent or controlling company, has its centre of activity, is registered or domiciled, or has its main place of business or substantial business activities, in the state concerned'. International extraterritorial obligations also include obligations to redress business-related human rights violations across state borders by ensuring that foreign victims have 'a prompt, accessible and effective remedy before an independent authority, including, where necessary, recourse to a judicial authority' (Principle 37).

The Maastricht Principles find support in various 'transnational', 'functional', and 'diagonal' approaches to extraterritorial human rights protection discussed in the literature (Altwicker 2018; Shany 2013; Knox 2010; Skogly and Gibney 2002). They build upon, and are further corroborated by, the interpretation of international extraterritorial obligations endorsed by the UN Treaty Bodies. Alongside general comments on extraterritorial state obligations concerning business activities that impact on the right to water, the right to work, and the right to social security, the Committee on Economic, Social, and Cultural Rights (CESCR) published in 2011 a statement on human rights and the corporate sector in which it called upon states to 'take steps to prevent human rights contraventions abroad by corporations which have their main seat under their jurisdiction, without infringing the sovereignty or diminishing the obligations of the host states under the Covenant' (CESCR 2011, para 5).

In its 2017 General Comment on State Obligations under the International Covenant on Economic, Social, and Cultural Rights in the Context of Business Activities, CESCR considered that:

Extraterritorial obligations arise when a state party may influence situations located outside its territory, consistent with the limits imposed by international law, by controlling the activities of corporations domiciled in its territory and/or jurisdiction, and thus may contribute to the effective enjoyment of economic, social and cultural rights outside its national territory.

(CESCR 2017, para 28)

Specifically concerning the extraterritorial obligation to protect, the Committee noted that "corporations domiciled in the territory and/or jurisdiction of states parties should be required to act with due diligence to identify, prevent and address abuses to Covenant rights by subsidiaries 
and business partners, wherever they may be located' (CESCR 2017, para 33). Regarding redress, states are duty-bound to remove legal and practical barriers to access to justice and effective remedies faced by victims of transnational corporate abuses, including 'by establishing parent company or group liability regimes' (CESCR 2017, para 44).

The other UN Treaty Bodies have expressed similar views. In a 2017 Communication concerning Canada's responsibility for human rights violations involving Canadian building companies in the occupied Palestinian territories, the Human Rights Committee noted that 'there are situations where a state party has an obligation to ensure that rights under the [International Covenant on Civil and Political Rights] are not impaired by extraterritorial activities conducted by enterprises under its jurisdiction' (HRC 2017, para 6.5). According to the Concurring Opinion of two Committee Members, the necessary jurisdictional link between the state and thirdcountry victims could be established on the basis of: '(a) the effective capacity of the state to regulate the activities of the businesses concerned and (b) the actual knowledge that the state had of those activities and their necessary and foreseeable consequences in terms of violations of human rights recognised in the Covenant' (HRC 2017, Concurring Opinion of Committee Members Olivier de Frouville and Yadh Ben Achour, para 10).

One important doctrinal justification behind this more robust approach to international extraterritorial obligations is the prohibition in customary international law, initially recognised in the context of transboundary pollution, for a state to use or permit the use of its territory such that it causes injury to another state or persons therein. In the Corfu Channel Case, the International Court of Justice derived from 'every state's obligation not to allow knowingly its territory to be used for acts contrary to the rights of other states' due diligence obligations to prevent such harmful acts from occurring or continuing (ICJ 1949, pp. 4, 22). In its Advisory Opinion on the Environment and Human Rights, the Inter-American Court of Human Rights linked states' due diligence obligations to prevent transboundary environmental harm to the human rights entitlements of third-country victims. According to the Court, the required jurisdictional link (Article 1 IACHR) could be established in virtue of a 'causal relationship' between the polluting activities within the state's borders and extraterritorial human rights violations, provided the state exercised 'effective control' over the relevant activities and was in a position to prevent the harm from occurring:

In cases of transboundary damage, the exercise of jurisdiction by a state of origin is based on the understanding that it is the state in whose territory or under whose jurisdiction the activities were carried out that has the effective control over them and is in a position to prevent them from causing transboundary harm that impacts the enjoyment of human rights of persons outside its territory. The potential victims of the negative consequences of such activities are under the jurisdiction of the state of origin for the purposes of the possible responsibility of that state for failing to comply with its obligation to prevent transboundary damage.

(IACtHR 2017, paras 102, 103)

The IACtHR's recognition of international extraterritorial obligations resonates with functional approaches to extraterritorial human rights protection considered under the ECHR and the EU Charter of Fundamental Rights (Moreno-Lax 2020; Moreno-Lax and Costello 2014). In his concurring opinion to Al Skeini, Judge Bonello envisaged a 'functional' approach to extraterritorial jurisdiction that should transcend the state-based territoriality/extraterritoriality divide:

Jurisdiction means no less and no more than 'authority over' and 'control of'. In relation to Convention obligations, jurisdiction is neither territorial nor extraterritorial: it ought to 
be functional ... The duties assumed through ratifying the Convention go hand in hand with a duty to perform and observe them. Jurisdiction arises from the mere fact of having assumed those obligations and from having the capacity to fulfil them (or not to fulfil them.

(ECtHR 2011, Concurring Opinion of Judge Bonello, paras 12, 13)

In a similar vein, the General Court of the European Union held in Front Polisario that EU institutions must protect foreign victims against the harmful human rights impacts of international trade agreements. According to the Court, the EU Charter of Fundamental Rights imposes extraterritorial obligations to "examine, carefully and impartially, all the relevant facts in order to ensure that the production of goods for export is not conducted to the detriment of the population of the territory concerned, or entails infringements of fundamental rights' (EGC 2012, para 228). ${ }^{2}$

\section{Towards an international business and human rights treaty}

International extraterritorial obligations are also at the heart of the draft international business and human rights treaty currently under negotiation. In June 2014, the UN Human Rights Council adopted Resolution 26/9 that established an open-ended intergovernmental working group on transnational corporations and other business enterprises with respect to human rights (OEIGWG), with a mandate to 'elaborate an international legally binding instrument to regulate, in international human rights law, the activities of transnational corporations and other business enterprises' (HRC 2014). In August 2020, the OEIGWG Chairmanship published a second revised draft (OEIGWG 2020). The revised draft treaty text clearly references the UNGPs' notion of corporate human rights due diligence, while also consolidating states' international extraterritorial human rights obligations to prevent and redress business-related human rights violations.

Regarding prevention, Article 6(1) of the 2020 draft provides that 'states parties shall regulate effectively the activities of all business enterprises within their territory or jurisdiction' or 'otherwise under their control' to ensure that these business enterprises 'respect all internationally recognised human rights and prevent and mitigate human rights abuses throughout their operations'. To comply with their international extraterritorial obligations, 'states parties shall require business enterprises to undertake human rights due diligence' concerning their own business activities and their business relationships with third parties (Article 6(2)). Regarding redress, Article 7(1) requires states parties to endow their domestic courts and non-judicial remedy mechanisms 'with the necessary jurisdiction ... to enable victims' access to adequate, timely and effective remedy'. This includes 'legal and other measures to necessary to ensure that [states'] domestic jurisdiction provides for effective, proportionate, and dissuasive criminal and/ or administrative sanctions' (Article 8(4)); and civil jurisdiction of domestic courts over tort claims brought by victims against business enterprises not domiciled in the forum state (Article 9). As an exception to the otherwise applicable lex loci delicti rule, Article 11 provides that, upon request of the victim, the applicable law in 'all matters of substance regarding human rights law' is that of the domestic (home state) court where the proceedings are brought.

If adopted, the international business and human rights treaty would further consolidate states' international extraterritorial obligations to prevent and redress business-related human rights violations, as envisaged by the Maastricht Principles (de Schutter 2015). To comply with their duty to protect, states must enact domestic legislation that imposes human rights due diligence requirements on business enterprises across their global supply/value chain; and ensure that their domestic jurisdiction provides for effective civil remedies and administrative and 
criminal sanctions for the benefit of foreign victims of business-related human rights violations. Different from earlier attempts to regulate the human rights impacts of global business enterprises in international law (UN Sub-Commission on Human Rights 2003), the draft treaty duly recognises that 'the primary obligation to respect, protect, fulfil and promote human rights ... lies with the state' (OEIGWG 2020, Preamble), while also placing existing examples of unilateral domestic regulation with extraterritorial effect on a secure multilateral footing.

\section{Home-state regulation in domestic law}

\section{Home-state regulation and the UNGPS}

Apart from forming an integral part of states' international extraterritorial obligations as envisaged by the Maastricht Principles, domestic regulation with extraterritorial effect also plays an important role in the implementation of the UN Guiding Principles on Business and Human Rights. The UNGPs are organised around three pillars: the state duty to protect human rights against violations by third parties, including business enterprises; the corporate responsibility to respect human rights, meaning to act with due diligence to avoid infringing the rights of others; and greater access to remedies, both judicial and non-judicial, for victims of business-related violations (HRC 2011).

As part of their responsibility to respect, business enterprises should carry out human rights due diligence (HRDD) to identify, prevent, mitigate, and account for how they address adverse human rights impacts they cause or contribute to through their own activities or which are directly linked to their operations, products, and services. As part of their duty to protect, states have to assume a proactive role in incentivising and, where necessary, requiring corporate respect for human rights through appropriate policies, legislation, adjudication, and enforcement. Home-state regulation of HRDD can thus contribute to a 'hardening' of the soft-law requirements bound up with the corporate responsibility to respect human rights (Nolan 2018; Macchi and Bright 2020). To close governance gaps at the global level, such regulation should include instruments with extraterritorial effect that reach out to corporate conduct abroad. Accordingly, the UN Working Group on Business and Human Rights tasked with overseeing states' implementation of the UNGPs, including through the development of National Action Plans (NAPs), has called upon governments to ensure that 'measures outlined in the NAP take full advantage of the leverage home states have in order to effectively prevent, address, and redress extraterritorial impacts of corporations domiciled within their territory and/or jurisdiction' (UNWG 2016, p. 19).

Neither the concept of home-state regulation nor the distinction between (nationality-based) direct extraterritorial jurisdiction and (territory-based) domestic measures with extraterritorial implications is new (Muchlinski 2007, pp. 125-140; Zerk 2010). Specifically in regulatory areas with a strong market nexus such as competition/antitrust, anti-bribery, and corruption, states rather commonly make use of domestic legislation to govern corporate conduct across territorial borders. Once the epistemic bias against 'extraterritoriality' is dispersed, the question becomes less whether states regulate corporations with extraterritorial effect than whether they do so to promote and protect human rights. In particular the earlier business and human rights NAPs show little evidence of states taking seriously the importance of extraterritorial regulation - an omission which, contra the UNGPs, risks to re-entrench the old dichotomy between mandatory international human rights norms and voluntary corporate social responsibility.

Meanwhile, states in Europe and elsewhere have enacted or consider enacting home-state regulation that renders legally binding (selective elements of) the UNGPs' HRDD requirements. 
Existing examples range from attempts to enhance corporate transparency through disclosure and reporting to the imposition of substantive due diligence obligations on business enterprises to protect human rights and the environment. While soft/voluntary measures incentivising corporate respect for human rights still dominate the regulatory landscape, states have made use of administrative, civil (corporate \& tort), and criminal law to monitor and enforce HRDD within corporate groups and throughout the global supply/value chain. To date, most enacted examples of home-state regulation are either sector-specific (e.g., preventing trade in conflict minerals and illegally harvested timber) or tailored to certain groups of rights holders (e.g., protecting children and victims of modern slavery).

\section{Transparency legislation}

Transparency legislation aims to promote corporate respect for human rights by imposing on business enterprises reporting and disclosure requirements concerning non-financial information about their global supply/value chains. Enhancing transparency should help investors and consumers to evaluate the human rights and environmental record of large companies and create market incentives for these companies to develop a more responsible and sustainable approach to business. The EU Non-Financial Reporting Directive, for example, considers that 'disclosure of non-financial information is vital for managing change towards a sustainable global economy by combining long-term profitability with social justice and environmental protection'. In line with the approach suggested by the UNGPs, reporting should cover 'the principal risks related to those matters linked to the undertaking's operations including, where relevant and proportionate, its business relationships, products or services which are likely to cause adverse impacts in those areas; and how the undertaking manages those risks' (Article 1(1)). The Directive allows for significant discretion as to what 'relevant and proportionate' information should be disclosed, and EU member states' implementation has tended to focus on risks to shareholders rather than risks to victims of business-related human rights and environmental harm (European Commission 2020, p. 166).

The California Transparency in Supply Chains Act (2010), the UK Modern Slavery Act (2015) and the Australian Modern Slavery Act (2018) aim to prevent forced labour in global supply chains by requiring companies to report on actions taken to eradicate slavery and human trafficking. According to Section 54 of the UK Modern Slavery Act, companies of a certain size which, wherever incorporated, carry out (part of their) business in the United Kingdom have to prepare an annual slavery and human trafficking statement. This statement 'may' include information about its policies and due diligence processes in relation to slavery and human trafficking throughout the supply chain. Alternatively, companies may simply declare that they have not taken steps to develop and implement HRDD policies and processes ('comply or explain'). The more recent Australian Modern Slavery Act lays down mandatory reporting requirements, including a company assessment of the effectiveness of measures taken to identify and address risks of modern slavery. A 2019 Norwegian legislative proposal on supply chain transparency moreover couples the monitoring of corporate reporting requirements with 'a right to information about fundamental human rights and working conditions in businesses and supply chains'- non-compliance with which attracts penalties (Norway Ethics Information Committee 2019, p. 36).

Transparency legislation was among the first attempts to ensure corporate respect for human rights by imposing on business actors and activities within the state's territorial jurisdiction reporting requirements that cover their global supply/value chain. Yet, on its own, transparency legislation does meet the requirements of the state duty to protect in international human rights law. Neither does it impose due diligence obligations on business enterprises, nor does it secure 
remedies to victims of business-related human rights violations. Moreover, existing examples of transparency legislation have proven of limited use in monitoring corporate respect for human rights and promoting HRDD policies and processes within companies (European Commission 2020; Alliance for Corporate Transparency 2019). A main challenge in this regard has been the poor quality of company responses (Mares 2018). Without sufficiently concrete and dedicated information, investors and consumers cannot use their purchasing power to reward companies for taking a proactive approach to human rights, nor can governments assess the effectiveness of their legislation. To play a meaningful part in the monitoring and enforcement of the corporate responsibility to respect human rights, transparency legislation needs to prescribe mandatory reporting requirements, based on concrete and tangible internationally recognised standards and indicators (Alliance for Corporate Transparency 2019; UK Government 2019).

\section{Market-based due diligence legislation}

Due diligence legislation combines corporate reporting with global supply/value chain due diligence requirements imposed on business actors and activities within the state's territorial jurisdiction. Apart from the business entity's place of incorporation ('parent-based' due diligence legislation), the necessary jurisdictional link can also be established in virtue of products and services placed on the state's domestic market ('market-based' due diligence legislation). On the former model, a business enterprise domiciled within the state's jurisdiction is legally required to exercise HRDD throughout its global supply chain. On the latter model, market access by business enterprises is conditional upon compliance with certain product and process (due diligence) standards protecting human rights and/or the environment abroad. Both models can be combined, for example, by imposing parent-based due diligence obligations on companies with substantial business activities within the state's territorial jurisdiction.

The first European Union 'market-based' instrument to impose mandatory due diligence obligations with extraterritorial effect was the EU Timber Regulation (EUTR), which aims to reduce illegal logging worldwide by prohibiting operators in Europe to place illegally harvested timber and timber products on the European market. Next to a requirement for traders of timber (products) to keep records of their suppliers and customers, EUTR obliges operators to develop a due diligence system to identify, assess, and mitigate the risk of illegally lodged timber (products) being sold in the European Union. EU Member States must apply 'effective, proportionate and dissuasive' penalties in case of non-compliance (Article 19), which may include fines and trading suspensions. A similar regulatory model underpins the 2012 Australian Illegal Logging Prohibition Act and - in the area of conflict minerals - the 2010 US Dodd-Frank Wall Street Consumer Protection Act and the new EU Conflict Minerals Regulation. The latter advances beyond EUTR in two regards: first, it requires EU importers of minerals and metals to incorporate their supply chain policy into agreements with suppliers, thus rendering the Regulation's due diligence standards legally binding between the contracting parties wherever located; and second, it requires EU importers of minerals and metals to establish or provide for an internal grievance mechanism that should function as an 'early-warning risk-awareness system' (Article 4).

In May 2019, the Dutch Senate adopted a Child Labour Due Diligence Law that imposes due diligence (gepaste zorgvuldigheid) obligations to prevent child labour in the supply chain on business enterprises selling goods and providing services to Dutch end-users. The Act, which has not yet entered into force, applies to all business enterprises (whether domiciled in the Netherlands or abroad) that supply goods and services to consumers in the Netherlands. Companies have to issue a statement that they conduct due diligence to prevent child labour in their supply 
chain (Article 4). This entails investigating reasonable suspicions of, and drawing up and implementing an action plan to address, child labour in their supply chain. The due diligence statements must be submitted to a supervisory authority that publishes them in a publically available online registry. Business enterprises providing goods and services to Dutch end-users can also discharge their due diligence obligations by sourcing from (lower-tier) companies that have issued a due diligence statement. In either case, due diligence is construed as a one-off exercise, which in the longer term limits the effectiveness of the legislation. The Act provides for public monitoring and enforcement that combines administrative and criminal sanctions, but does not include civil remedies for victims of child labour.

Market-based due diligence legislation conditions market-access by business enterprises upon compliance with substantive due diligence requirements that reach out into the global supply/value chain. While this addresses some of the shortcomings of transparency legislation in ensuring corporate respect for human rights, existing examples of home-state regulation in this area do not fully implement the UNGPs (Macchi and Bright 2020), nor do they satisfy the requirements of the state duty to protect in international human rights law. Confining the scope of market-based due diligence legislation to particular sectors and/or groups of rights holders contravenes the universality and indivisibility of human rights. Most existing examples of 'market-based' due diligence legislation moreover lack a dedicated human rights focus, which considerably limits their capacity to mainstream HRDD into corporate practice (McCorquodale et al. 2017). Finally, as the main concern of market-based due diligence legislation lies with the protection of domestic consumers, it does not include civil remedies for victims of businessrelated human rights violations inside or outside the state's territorial jurisdiction.

\section{Parent-based due diligence legislation}

To date, the only general parent-based due diligence law that covers human rights and environmental impacts and that also includes civil remedies is the 2017 French Duty of Vigilance Law. The law imposes 'vigilance' obligations on large companies with a registered office in France, including subsidiaries of foreign companies. These due diligence obligations extend to all (directly or indirectly) controlled companies as well as to activities of subcontractors and suppliers within established commercial relationships. At the heart of the law is a threefold obligation to enact, implement, and disclose a plan de vigilance that must contain reasonable due diligence measures to identify risks and prevent serious harm to human rights, fundamental freedoms, the health and safety of individuals, and the environment. In case of non-compliance, interested parties including civil society organisations can serve a notice to companies and subsequently seek an injunction backed up by periodic penalty payments. This mechanism has been used in a number of instances, with court decisions still pending (Brabant and Savourey 2020). In addition, the Duty of Vigilance Law creates a civil liability regime that enables (foreign) victims to sue the parent/controlling company in France for human rights and environmental damages in its global supply chain. As the civil liability mechanism has not yet been used, it remains unclear whether the substantive provisions of the law would apply in cases where the damage occurs outside France. ${ }^{3}$

The German National Action Plan, released in 2016, set the goal of at least $50 \%$ of German companies with more than 500 employees having implemented human rights due diligence by 2020 (German Federal Foreign Office 2016). As government monitoring of the NAP's implementation suggested that the $50 \%$ benchmark would not be met, the Federal Ministry for Labour and Social Affairs and the Federal Ministry for Economic Cooperation and Development drafted the cornerstones of a general value chain due diligence law. The German Supply 
Chain Due Diligence Act adopted in June 2021 bears the mark of protracted political negotiations and falls behind the standards set in earlier proposals and drafts (Initiative Lieferkettengesetz.de 2021). The law's due human rights and environmental due diligence obligations are principally limited to direct suppliers, with HREDD further down the supply chain only being required where a company fraudulently circumvents the direct supplier or obtains substantiated knowledge of potential human rights abuses by indirect suppliers. While NGOs and trade unions are empowered to represent victims in civil proceedings before German courts, the law does not explicitly provide for civil liability for harm incurred through violations of corporate due diligence obligations.

The enactment of parent-based due diligence legislation has also been announced or is being considered in various other European countries and in the European Union. In March 2021, a coalition of Dutch political parties proposed a new Bill for Responsible and Sustainable International Business Conduct which, different from the earlier Dutch Child Labour Due Diligence Law, would impose cross-sectoral human rights and environmental due diligence obligations across the global value chain; and would provide for civil remedies in addition to administrative and criminal sanctions (MVO Platform 2021). The 2019 Norwegian legislative proposal on a supply chain transparency envisages imposing on 'larger enterprises' substantive due diligence obligations to 'identify, prevent and mitigate possible adverse impacts on fundamental human rights and decent work and account for how they address any adverse impacts' (Norway Ethics Information Committee 2019, p. 57). A popular initiative in Switzerland to make human rights and environmental supply chain due diligence mandatory for Swiss-based companies by amending the Swiss constitution (Swiss Responsible Business Initiative 2015) was narrowly rejected in a public referendum in late November 2020. The original proposal would have enabled foreign victims of human rights and environmental harm to seek civil redress in Switzerland, with a company's exercise of adequate due diligence serving as a defence against liability. The compromise reached in June 2020 between the Swiss Council of States and the Swiss National Council, which now renders into effect, only contains sector-specific due diligence requirements (child labour and conflict minerals) and no civil liability mechanism.

Following the publication of a major due diligence study (European Commission 2020) and increasing calls by all groups of relevant stakeholders for a Europe-wide HRDD legislation, the European Parliament's Committee on Legal Affairs tabled a motion for a European Parliament Resolution recommending a European Directive on Corporate Due Diligence and Corporate Accountability, which the Parliament adopted in a landslide vote in March 2021 (European Parliament 2021). If enacted, the directive would provide for the most comprehensive regulation of corporate due diligence and corporate accountability, in line with the UNGPs (Augenstein and Macchi 2021). The EP Resolution envisages EU Member States to require business enterprises domiciled in the European Union and/or placing products in the internal market to exercise human rights and environmental due diligence throughout their global value chains. It would further require Member States to impose tort liability on business enterprises for human rights and environmental harm, with the exercise of due diligence serving as a defence. To ensure that the Directive's HRDD requirements also apply in transnational tort litigations for damages that occurred outside the European Union, Member States are to denomiate these requirements as overriding mandatory provisions of the forum. ${ }^{4}$ A European Commission legislative initiative that was initially expected for summer 2021 has been delayed as the EP Resolution did not pass the Commission's regulatory scrutiny board.

Existing examples of parent-based legislation only impose due diligence obligations on large or larger companies and restrict their reach into the global value chain (Krajewski 2020, pp. 10-11). The German Supply Chain Due Diligence Act unduly discriminates between direct 
(first-tier) and indirect suppliers. The French Duty of Vigilance Law exonerates small and medium-sized enterprises and limits supply chain due diligence to 'established business relationships' - whereas the UNGPs cover all adverse human rights impacts 'which may be directly linked to [the business enterprise's] operations, products or services by its business relationships' (HRC 2011, Principle 17a). Such priori restrictions of the scope and scale of parent-based due diligence legislation is also incompatible with states' international extraterritorial obligations, which as interpreted by the Maastricht Principles only require 'a reasonable link between the state concerned and the conduct it seeks to regulate, including where the relevant aspects of a non-state actor's activities are carried out in that state's territory' (Principle 25(d)). To comply with their duty to protect, states should ensure that due diligence obligations apply to all business actors and activities within their territorial jurisdiction and extend across the entire supply/value chain. A company's size and its operational remoteness from the human rights harm should be accounted for by proportionality and/or reasonableness criteria built into the due diligence requirements. The French law is currently the only example of states' implementation of their international extraterritorial obligation to redress business-related human rights violations that includes a civil remedy mechanism - this notwithstanding that civil redress is a core ingredient of the human right to remedy and remains a major concern in the effective implementation of the UNGPs (HRC 2016).

\section{Conclusion}

The chapter set out by distinguishing two legal issues pertinent to the home-state regulation of corporations. First, the extent to which international law imposes obligations on states to prevent and redress business-related human rights violations for the benefit of individuals located outside their territory; and second, the extent to which states could and should use domestic law to regulate the extraterritorial human rights impacts of business enterprises. While both issues remain subject to considerable political debate, the chapter argued that states' increasing use of domestic regulation with extraterritorial effect goes hand-in-hand with the incremental recognition of international extraterritorial obligations to prevent and redress business-related human rights violations. The chapter interpreted these developments in terms of a gradual convergence between the regulatory models that underpin both domains of legal ordering. It was argued that this convergence is evidence of a growing recognition among states that corporate respect for human rights should be brought under the purview of international human rights law such that states' domestic regulation of the global human rights impacts of business enterprises becomes anchored in international legal obligations towards foreign victims of business-related human rights violations. As envisaged by the Mastricht Principles, international extraterritorial obligations thus not only reinforce the primary obligation of states to respect, protect, and fulfil human rights in international law but may also contribute to a more effective implementation of the UNGPs through domestic regulation with extraterritorial effect that addresses existing shortcomings of home-state regulation.

\section{Notes}

1. The terminology used by international courts and treaty bodies is not uniform and does not yield an unequivocal distinction between authority, power, and control. It appears useful to distinguish between effective control as de facto power and control as de jure authority, which recognises the difference between the facticity of coercion and the normative command to act in accordance with the law.

2. The judgment was quashed on appeal for lack of standing of the applicants under Article 263 TFEU. 
3. As an exception to the otherwise applicable lex loci delicti rule; see Article 4 Regulation (EC) No $864 / 2007$ of the European Parliament and of the Council of 11 July 2007 on the law applicable to non-contractual obligations.

4. Two annexes to the Committee on Legal Affairs' proposal that envisaged a more comprehensive reform of EU private international law to address barriers to access to justice encountered by thirdcountry victims of human rights and environmental harm were not included in the final resolution. A more comprehensive reform of EU private international law envisaged in two Annexes to the Committee of Legal Affairs'initial proposal.

\section{Bibliography}

Alliance for Corporate Transparency (2019) Research Report 2019: An analysis of the sustainability reports of 1000 companies pursuant to the EU Non-Financial Reporting Directive, available at: https://www. allianceforcorporatetransparency.org/ [accessed 28 July 2021].

Altwicker, T. (2018) 'Transnationalising Rights: International Human Rights Law in Cross-Border Contexts' European Journal of International Law 29(2), 581-606.

Augenstein, D. (2018) ‘Torture as Tort? Transnational Tort Litigation for Corporate-Related Human Rights Violations and the Human Right to Remedy' Human Rights Law Review 18(3), 593-612.

Augenstein, D. and Kinley, D (2013) 'When Human Rights "Responsibilities" become "Duties": The Extraterritorial Obligations of States that bind Corporations' in Deva, S. and Bilchitz, D. (eds.) Obligations of Business: Beyond the Corporate Responsibility to Respect?, Cambridge University Press, 271-294.

Augenstein, D. and Macchi, C. (2021), The Role of Human Rights and Environmental Due Diligence Legislation in Protecting Women Migrant Workers in Global Food Supply Chains, available at: https://papers.ssrn.com/ sol3/papers.cfm?abstract_id $=3847676$ [accessed 28 July 2021].

Besson, S. (2012) 'The Extraterritoriality of the European Convention on Human Rights: Why Human Rights Depend on Jurisdiction and What Jurisdiction Amounts to' Leiden Journal of International Law 25(4), 857-884.

Brabant, S. and Savourey, E. (2020) 'All Eyes on France - French Vigilance Law First Enforcement Cases (1/2)' Cambridge Law Blog.

Committee on Economic, Social and Cultural Rights (2011) Statement on the Obligations of States Parties Regarding the Corporate Sector and Economic, Social and Cultural Rights, E/C.12/2011/1.

Committee on Economic, Social and Cultural Rights (2017), GC 24 on State Obligations under the International Covenant on Economic, Social and Cultural Rights in the Context of Business Activities, E/C.12/GC/24.

de Schutter (2015) 'Towards a New Treaty on Business and Human Rights' Business and Human Rights Journal 1, 41-67.

den Heijer, M. and Lawson, R. (2013) 'Extraterritorial Human Rights and the Concept of Jurisdiction', in Langford M., Vandenhole W., Scheinin, M. and van Genugten, W. (eds.) Global Justice, State Duties, Cambridge University Press, 153-191.

ETO Consortium (2011) Maastricht Principles on Extraterritorial Obligations of States in the Area of Economic, Social and Cultural Rights.

European Commission (2020) Study on Due Diligence Requirements through the Supply Chain, Final Report, available at: https://op.europa.eu/en/publication-detail/-/publication/8ba0a8fd-4c83-11eab8b7-01aa75ed71a1/language-en [accessed 28 July 2021].

European Court of Human Rights (2006) Markovic and Others v. Italy, Application No: 1398/03, Judgment (Merits).

(2010) Rantsev v. Cyprus \& Russia, Application No: 25965/04, Judgment (Merits).

(2011) Al-Skeini and Others v. United Kingdom, Application No: 66721/07, Judgment (Merits).

(2012) Nada v. Switzerland, Application No: 10593/08, Judgment (Merits)

(2015) Sargsyan v. Azerbaijan, Application No: 40167/06, Judgment (Merits).

(2016) J.K. and Others v. Sweden, Application No: 59166/12, Judgment (Merits). 
European Parliament (2021) Resolution of 10 March 2021 with Recommendations to the Commission on Corporate Due Diligence and Corporate Accountability (2020/2129(INL), A9-0018/2021.

German Federal Foreign Office (2010) National Action Plan: Implementing the UN Guiding Principles on Business and Human Rights 2016-2020, available at: https://www.auswaertiges-amt.de/de/aussenpolitik/themen/aussenwirtschaft/wirtschaft-und-menschenrechte/-/227580 [accessed 28 July 2021].

General Court of the European Union (2012) Case T-512/12 Front Polisario, ECLI:EU:T:2015:953.

Human Rights Committee (2017) Basem Ahmed Issa Yassin et al. v. Canada, Communication No. 2285/2013, CCPR/c/120/D/2285/2013.

Human Rights Council (2008) Protect, Respect and Remedy: A Framework for Business and Human Rights, A/HRC/8/5.

(2011) Guiding Principles on Business and Human Rights: Implementing the United Nations' 'Protect, Respect and Remedy' Framework, A/HRC/17/31.

(2014) Elaboration of an International Legally Binding Instrument on Transnational Corporations and Other Business Enterprises with Respect to Human Rights, A/HRC/Res. 26/9.

(2016) Improving Accountability and Access to Remedy for Victims of Business-related Human Rights Abuse, A/HRC/32/19.

Initiative Lieferkettengesetz.de (2021), What the new Supply Chain Act delivers - and what it doesn't, available at: https://lieferkettengesetz.de/pressemitteilung/german-parliament-passes-supply-chainlaw/ [accessed 28 July 2021].

Inter-American Commission of Human Rights (1999), Coard v. United States, Report No. 109/99.

Inter-American Court of Human Rights (2017) Advisory Opinion OC-23/17 requested by the Republic of Colombia:The Environment and Human Rights, Series A No. 23.

International Court of Justice (1949) Corfu Channel Case (United Kingdom v. Albania), ICJ Rep 4.

(2004) Legal Consequences of the Construction of a Wall in the Occupied Palestinian Territory, ICJ Rep 136.

Knox, J. (2010) 'Diagonal Environmental Rights', in Gibney M. and Skogly S. (eds.) Universal Human Rights and Extraterritorial Obligations, University of Pennsylvania Press, 82-103.

Krajewski, M. (2020) 'Human Rights Due Diligence Legislation - Options for the EU' Policy Briefing for the European Parliament's Subcommittee on Human Rights, PE 603.495.

Macchi, C. and Bright, C. (2020) 'Hardening Soft Law: The Implementation of Human Rights Due Diligence Requirements in Domestic Legislation', in Buscemi, M., Lazzerini, N. and Magi, L. (eds.) Legal Sources in Business and Human Rights - Evolving Dynamics in International and European Law, Brill Publishers, 218-247.

Mares, R. (2018) 'Corporate Transparency Laws: A Hollow Victory?' Netherlands Quarterly of Human Rights 36(3), 189-213.

McCorquodale, R., Smit, L., Neely, S. and Brooks, R. (2017) 'Human Rights Due Diligence in Law and Practice: Good Practices and Challenges for Business Enterprises' Business and Human Rights Journal 2 , 195-224.

Moreno-Lax, V. (2020) 'The Architecture of Functional Jurisdiction: Unpacking Contactless Control - On Public Powers, S. S. and Others v. Italy, and the "Operational Model"' German Law Journal 21, 385-416.

Moreno-Lax, V. and Costello C. (2014) 'The Extraterritorial Application of the EU Charter of Fundamental Rights: From Territoriality to Facticity, The Effectiveness Model', in Peers, S. et al. (eds.) Commentary on the EU Charter of Fundamental Rights, Oxford University Press, 1657-1683.

Muchlinski, P. (2007) Multinational Enterprises and the Law, $2^{\text {nd }}$ edn, Oxford University Press.

MVO Platform (2021), Translation of the Bill for Responsible and Sustainable International Business Conduct, available at: https://www.mvoplatform.nl/en/translation-of-the-bill-for-responsible-and-sustainable-international-business-conduct/ [accessed 28 July 2021].

Nolan, J. (2018) 'Hardening Soft Law: Are the emerging corporate social disclosure and due diligence laws capable of generating substantive compliance with human rights norms? Revista de Direito Internacional 15(2), 65-83. 
Norwegian Ethics Information Committee (2019) Supply Chain Transparency: Proposal for an Act regulating Enterprises' transparency about supply chains, duty to know and due diligence, available at: https:// www.regjeringen.no/en/dokumenter/supply-chain-transparency/id2680057/ [accessed 28 July 2021].

OEIGWG Chairmanship (2020) Second Revised Draft: Legally Binding Instrument to Regulate, in International Human Rights Law, the Activities of Transnational Corporations and Other Business Enterprises.

Shany, Y. (2013) 'Taking Universality Seriously: A Functional Approach to Extraterritoriality in International Human Rights Law' The Law and Ethics of Human Rights 7(1), 47-71.

Skogly, S. and Gibney, M. (2002) 'Transnational Human Rights Obligations' Human Rights Quarterly 24, 781-798.

Swiss Coalition for Corporate Justice (2015) 'The Initiative Text with Explanations', available at: https:// corporatejustice.ch/about-the-initiative/ [accessed 28 July 2021].

UK Government (2019) 'Independent Review of the Modern Slavery Act: Final Report', available at: https://www.gov.uk/government/publications/independent-review-of-the-modern-slavery-actfinal-report [accessed 28 July 2021].

UN Sub-Commission on the Promotion and Protection of Human Rights (2003) Draft Norms on the Responsibilities of Transnational Corporations and Other Business Enterprises with Regard to Human Rights, E/CN.4/Sub.2/2003/12.

UN Working Group on Business and Human Rights (2016) 'Guidance on National Action Plans on Business and Human Rights'.

Zerk, J. (2006) Multinationals and Corporate Social Responsibility, Cambridge University Press.

(2010) 'Extraterritorial Jurisdiction: Lessons for the Business and Human Rights Sphere from Six Regulatory Areas' Corporate Social Responsibility Initiative Working Paper No. 59, John F. Kennedy School of Government, Harvard University. 